\title{
DIETARY EFFECTS ON RUMINANT LIVESTOCK REPRODUCTION WITH PARTICULAR REFERENCE TO PROTEIN
}

\author{
H. KAUR AND S. P. ARORA \\ Division of Dairy Cattle Nutrition, National Dairy Research Institute, Karnal-132001, \\ India
}

\section{CONTENTS}

INTRODUCTION . . . . . . . . . . . . . . . . . 121

EFFECTS OF PROTEIN NUTRITION ON REPRODUCTION . . . . 122

PUBERTY . . . . . . . . . . . . . . . 122

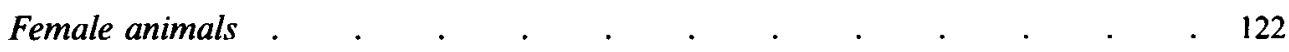

Male animals . . . . . . . . . . . . . . . . . .

OESTROUS CYCLE .

OVULATION RATE .

CONCEPTION . . . . . . . . . . . . . . . . . . . . . . . . 124

EMBRYO SURVIVAL .

FETAL GROWTH AND NEONATAL VIABILITY . . . . . . . . . . . . . . . 125

POSTPARTUM ANOESTROUS INTERVAL .

POSSIBLE MECHANISMS OF EFFECTS OF PROTEIN NUTRITION ON

REPRODUCTION . . . . . . . . . . . . . . . . .

PUBERTY .

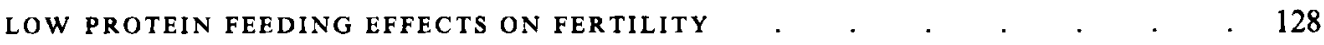

HIGH PROTEIN FEEDING EFFECTS ON FERTILITY . . . . . . . . . . . . $\quad$. 128

CONCLUSIONS AND PERSPECTIVES . . . . . . . . . . . . . . 129

REFERENCES . . . . . . . . . . . . . . . . . . 130

\section{INTRODUCTION}

The process of reproduction is a coordinated function of many tissues, cell types and regulatory systems which is possible only when animals are provided with sufficient quantities of dietary nutrients. The livestock industry is faced with different situations as far as protein nutrition is concerned in different countries. In most of the Third World countries, animals survive on poor quality roughages and crop residues which are deficient in many essential nutrients. The major constraint in such feeds is protein deficiency because the digestible crude protein content of these roughages is very low. In certain Asian and African countries, animals generally graze without much feed supplement (Leng, 1990). Thus, the availability of nutrients, particularly protein, remains inadequate most of the year except during the rainy season or for some period thereafter and it is during this period that regular oestrous cycles are normally exhibited. Crossbreeding programmes have been adopted in some of the developing countries and thus a considerable population of improved cows has emerged. They require balanced nutrition for exploitation of their genetic potential so far as milk production is concerned. To some extent protein deficiency 
is being overcome by mixing urea or other non-protein nitrogen substances in the total diet or by treating crop residues with these substances. A limit to urea feeding is necessary, however, otherwise ammonia levels in the rumen and blood may increase and have a detrimental effect on reproduction.

In developed countries, where feeds of higher protein content are given to increase milk production, the situation is quite different. However, too high a level of dietary protein can result in reduced fertility in dairy cows (Khasan et al. 1989) and decreasing the protein supply to $80 \%$ of National Research Council (Pangborn, 1978) or $75 \%$ of Agricultural Research Council (Treacher et al. 1976) recommendations can lead to improved fertility. This question of optimal protein content has been partly resolved by considering the extent of degradation of dietary proteins in the rumen. Thus, two types of protein requirements have been suggested for ruminants (Agricultural Research Council, 1980; National Research Council, 1989): the requirements of the animal itself and of the rumen microbial population. In this review the effect of protein nutrition on various reproductive functions in ruminant animals is discussed, including likely mechanisms.

\section{EFFECTS OF PROTEIN NUTRITION ON REPRODUCTION}

\section{PUBERTY}

\section{Female animals}

Improving the fertility and lifetime efficiency of dairy animals is of great concern. It is well documented that the age at puberty is lower in rapidly growing animals (Arije \& Wiltbank, 1971; Dufour, 1975; Shokamoto et al. 1975). The concept of target weight developed by Lamond (1970) is highly pertinent because puberty is a function of live weight rather than age which is evident both in cows and buffaloes (Dufour, 1975; Kaur \& Arora, 1989). In other words, it is a rapid achievement of body size and weight which are prerequisites for the prompt onset of puberty. Even fetal growth is important because it has a bearing on birth weight which is correlated with growth rate. In semi-arid zones of the tropics, puberty is usually delayed in grazing cattle because grasslands do not provide enough protein and other nutrients (Topps, 1977). This low protein content of tropical grasses leads to insufficient production of rumen microbial protein to support optimum growth rate (Oyedipe et al. 1982). Poor growth rate due to low plane of nutrition delayed puberty in cows (Day et al. 1986) and goats (Doney et al. 1982). In temperate zones also, hill grazing is reported to be insufficient to support the potential growth in sheep and goats, resulting in a delay of puberty of up to one year (Dýrmundsson, 1987; Loudon, 1987).

Murrah buffalo calves given $37.0 \%$ less crude protein and $16.2 \%$ less total digestible nutrients than National Research Council (1978) requirements gained $397.5 \mathrm{~g} / \mathrm{d}$ as compared to $570.2 \mathrm{~g} / \mathrm{d}$ in control calves. The weight at first oestrus averaged 343 and $341 \mathrm{~kg}$ respectively, but underfed heifers exhibited a delay of 210 days in attaining first oestrus (Kaur \& Arora, 1989). Similarly, Malik (1987) indicated that buffalo heifers maintained on a higher plane of nutrition showed first oestrus at an early age due to a higher growth rate. Therefore, the onset of puberty seems to be determined by weight gain achieved during the postweaning period, rather than by the age of the animal.

\section{Male animals}

An inverse relationship between growth rate and age at puberty also exists in males (Waddad \& Gaili, 1985). Low protein feeding has been shown to delay puberty by about five months in Nigerian bulls and their Friesian crosses (Rekwot et al. 1987) and such bulls 
had poor testicular development and smaller ejaculates as compared to their normal counterparts (Rekwot et al. 1988). Young bulls kept on grazing plus concentrate feed showed better growth rate than those on grazing alone, with an earlier age at puberty and a greater scrotal circumference (Perry et al. 1991; Tegegne et al. 1992). Even at maturity, the size of the testicles is smaller in underfed animals resulting in a lower sperm concentration in the semen (VanDemark et al. 1964). It has also been reported that the seminal vesicles contain less fructose and citric acid as well as smaller Leydig cells and seminiferous tubules, and decreased testosterone level under protein stress conditions (Nolan et al. 1990). Even older bulls were susceptible to low dietary protein and showed decreased testicular size and reduced fertility than those adequately fed (Lindsay et al. 1982; Rekwot et al. 1988). Restriction of both protein and energy also prevented Merino lambs from reaching puberty in their first potential breeding season (Ketut Sutama \& Edey, 1985 ), with reduced testicular size and sperm concentration in the ejaculate (Parker \& Thwaites, 1972; Oldham et al. 1978; Foote, 1978; Alkass et al. 1982). Feed restriction also reduced libido in rams (Parker \& Thwaites, 1972).

\section{OESTROUS CYCLE}

Deficiency of protein and/or energy has been reported to result in cessation of oestrous cycles (Louw et al. 1988; Richards et al. 1989), a loss of $15 \%$ body weight being critical to cause infertility in cows. The phenomenon of cessation of oestrous cycles has been observed in cows in winter months and in buffaloes in summer months. The proportion showing oestrus was only $63 \%$ in winter months and $43 \%$ in summer months in underfed buffaloes as compared to oestrus detection of 100 and $89 \%$ respectively in well fed buffaloes. The mean anoestrous period was 21.8 and $159.8 \mathrm{~d}$ in buffaloes at optimum and deficient levels respectively (Kaur \& Arora, 1982). The anoestrous period recorded in cows was $170.3 \mathrm{~d}$ in a deficient group and $36.3 \mathrm{~d}$ in normal animals (Juneja \& Arora, 1990). Such an effect may be due to ovarian dysfunction resulting in a very low progesterone level both in cows and buffaloes. The disruption of pulsatile luteinizing hormone (LH) release affects follicular development and leads to an anoestrous condition. The day of the cycle at which progesterone peaked was 13.7 in the case of malnourished cows as compared to 12.6 in well fed animals, showing a slower development of the corpus luteum during the luteal phase. Oestrous cycle length has also been observed to increase as a result of dietary protein deficiency, reported as $21.4 \mathrm{~d}$ in deficient as compared to $19.4 \mathrm{~d}$ in normal cows (Juneja \& Arora, 1989). In buffaloes, oestrous cycle length in deficient animals has been recorded to be $23.2 \mathrm{~d}$ as compared to $22.7 \mathrm{~d}$ in normally fed animals (Kaur \& Arora, 1982). Sasser $\boldsymbol{e t}$ al. (1988) reported a $29 \%$ reduction in oestrous cycles on a low dietary protein intake of $320 \mathrm{~g}$ as compared to control given $960 \mathrm{~g}$ daily.

Following severe undernutrition, optimal feeding rapidly restores pituitary and gonadal functions. Foster $e t$ al. (1988) observed that suppression of $\mathrm{LH}$ and follicle stimulating hormone secretion in undernourished lambs was reversed within $2 \mathrm{~d}$ of changing their feeding level. Kaur (1981) reported an increase in plasma progesterone concentration within $8 \mathrm{~d}$ of a shift to optimum feeding in an underfed buffalo. An increase in progesterone concentration was also recorded a few days prior to the onset of oestrus after a long anoestrous period. It has been suggested that the increase in progesterone concentration is of intraovarian luteal tissue origin (Berardinelli et al. 1979) and is required to stimulate the frequency of LH pulses (Smith \& Day, 1990). The initial LH surge may cause luteinization of follicles rather than ovulation. Subsequent LH surges may be followed by ovulations and oestrous cycles of normal length (Schillo et al. 1992). 


\section{OVULATION RATE}

Adequate nutrition during prenatal and postnatal periods is essential in all species for optimum ovulation rate (Doney et al. 1982; Henniawati \& Fletcher, 1986). Ewes are usually provided with extra food for a few weeks before mating (flushed) to increase the proportion of multiple ovulations and multiple births (Smith, 1988; Teleni et al. 1989; Abecia et al. 1993). Conversely, feeding low protein diets has an adverse effect on ovulation rate (Davis et al. 1981; Stewart \& Oldham, 1986; Nottle et al. 1988). Ewes maintained on temperate hill grazing or in the arid or semi-arid zones are usually deficient in protein and energy and their ovulation rate has been reported to average less than one in a single oestrous period (Rhind et al. 1986). An increase in ovulation rate by 8-25 ovulations per 100 ewes given protein supplement before mating had been observed and the blood levels of leucine, isoleucine and valine were about twice those in the protein supplemented group (Waghorn et al. 1990). Abecia et al. (1993) did not observe any effect of protein supplementation (120 v. $95 \mathrm{~g} /$ head daily) after weaning in the month of July on the onset of breeding or ovulation rate at first oestrus in ewes, but the effect was evident at mid term in subsequent oestrous cycles in the month of September. An increase in the protein level during the transitional period from anoestrus to the onset of the breeding period did not raise the ovulation rate in the first cycle in contrast to the results obtained within the breeding season (Radford et al. 1980; Smith et al. 1990; Pearse et al. 1991). Ewes exhibiting multiple ovulations in the first cycle after weaning experienced advanced onset of breeding (Baird \& McNeilly, 1981; Karsch, 1984). The higher ovulation rates in ewes in good body condition reflect their greater number of large ovarian follicles in the late luteal phase of the preceding oestrous cycle (Rhind \& McNeilly, 1986; Rhind et al. 1989; Xu et al. 1989). The changes that determine the number of ova to be released in response to variation in the level of dietary protein intake are still not clear. It seems that higher protein levels increase the concentration of insulin (Smith, 1988), which enhances the activity of certain hepatic enzymes; in consequence there is likelihood of increased catabolism of steroid hormones (Thomas et al. 1987) resulting in reduced circulatory levels. Thus, the negative feedback effect of steroids on the anterior pituitary is reduced, leading to increased gonadotrophin secretion (Ritar \& Adams, 1988) resulting in a higher ovulation rate.

\section{CONCEPTION}

Protein inadequacy has an important bearing on survival of embryos and development of the fetus during pregnancy in domestic animals (Folman et al. 1983; Robinson, 1990). Lower conception rates have been observed as a result of underfeeding in cows (Meaker, 1976; Kaim et al. 1983; Baruah et al. 1986; Fletcher et al. 1987) either due to fertilization failure or some other ovarian dysfunction. In buffaloes, the conception rate at first service has been reported to be $66.7 \%$ in normal as compared to $16.7 \%$ in protein deficient animals (Kaur, 1993). In another study, 2.66 inseminations were recorded in normally fed as compared to more than 4.00 inseminations per conception in protein deficient buffalo heifers (Kaur \& Arora, 1989). Likewise Juneja \& Arora (1986) reported $2 \cdot 25$ services per conception in protein deficient as compared to 1.50 inseminations per conception in normal cows, while Sasser et al. (1988) reported conception rates of $32 \%$ in deficient cows and $74 \%$ in normal protein counterparts. Such reports of lower conception rate have also appeared in ewes (Abdul-Wahid et al. 1986). The effects of protein deficiency on conception rate may be confounded due to overlapping of events such as peak milk production and return to cyclic sexual function in lactating animals (Stevenson \& Call, 1988; Swanson, 1989). Feeding of high protein diets has been found useful in increasing the dry matter 
intake of high yielding animals (Davis, 1978; Wohlt \& Clark, 1978) with a resultant increase in milk production (Leng \& Nolan, 1984). On the other hand, Oldham (1984) reported that high crude protein levels which promoted milk production have an adverse effect on subsequent fertility. In many other studies, higher crude protein intake either had no effect or it led to more services per conception (Howard et al. 1987; Khasan et al. 1989). Ferguson \& Chalupa (1989) applied logistic regression analysis to the existing data on protein effects on reproduction in lactating cows in order to find out the impact of rumen degradable protein (RDP) and undegradable dietary protein on conception rate. They suggested that an intake of RDP in excess of rumen requirements is associated with decreased conception rate in dairy cows. Ferguson $e t$ al. (1988) recorded an increase in conception rate from 23.0 to $46.2 \%$ in dairy cows when the dietary protein was reduced from 184 to $160 \mathrm{~g} / \mathrm{kg}$ and its RDP content from 67 to $62 \%$.

\section{EMBRYO SURVIVAL}

Prolonged underfeeding has been reported to cause a significant reduction in the survival and development of embryos in cows and sheep (Parr et al. 1982, 1986; Robinson, 1986). Rhind et al. (1989) did not observe any difference in fetal size between days 21-26 in ewes maintained on 50 and $150 \%$ of their maintenance protein needs in early pregnancy. However, a higher plane of nutrition has been reported to reduce embryo survival rate in ewes (Parr et al. 1987). Higher protein or energy intakes have a stimulatory effect on hepatic blood flow which influences the metabolic clearance rate of progesterone (Symonds \& Prime, 1989) causing its decrease to an extent that may compromise embryo survival and growth (McKelvey \& Robinson, 1986). In this context, Parr et al. (1987) demonstrated that the reduction in the rate of embryo survival arising as a result of a higher plane of protein and energy nutrition can be avoided by administration of exogenous progesterone. Differences in circulating progesterone level due to dietary protein status may bring about changes in the production of either trophoblastic proteins or endometrial secretory proteins (Stone, 1987). Levels of ten such endometrial proteins have been shown to increase during early pregnancy with the administration of exogenous progesterone (Ashworth \& Bazer, 1989) in animals fed on a higher plane of nutrition which might be an essential mechanism for embryo survival (Thatcher et al. 1989; Bazer, 1989). It may also be possible that a low plane of nutrition and in consequence higher progesterone level may modify the secretory pattern of IGF binding proteins from the blastocyst and this requires further investigation of its involvement in embryo survival (Corps et al. 1989).

In embryo transfer experiments, a positive relationship has been established between embryo quality and feeding level as evidenced through maternal blood glucose concentration from the time of ovulation up to embryo recovery from the donor ewes (McKelvey \& Robinson, 1988). Waghorn \& Smith (1990) synchronized oestrus in 20 ewes and divided them into two groups for feeding low and high protein $(133 \mathrm{v} .271 \mathrm{~g} / \mathrm{kg})$ diets. The number of ova recovered per ewe increased from 1.47 to 1.89 in the high protein group and from 1.35 to 1.50 in the low protein group.

\section{FETAL GROWTH AND NEONATAL VIABILITY}

Maternal dietary protein restriction during pregnancy can affect fetal growth through lack of supply of certain amino acids to the fetal tissues and may reduce the birth weight of offspring (Dunn, 1980; Robinson, 1983, 1990). During late pregnancy in cows, the protein and energy requirements are 1.5 times the maintenance needs and any deficiency may lead 
to restricted growth (Wright et al. 1986; Topps et al. 1989). Additional dietary protein intake to the extent of $0.3-0.5$ times above maintenance during pregnancy proved adequate in ewes (Robinson \& McDonald, 1989). Restriction of feed intake to 0.15 times maintenance requirement showed arrested growth of the fetuses in ewes during early pregnancy, resulting in a specific effect in the proximal tibial metaphysis with consequent lower lamb live weight at birth (Vincent et al. 1985). The condition of the uterus at the time of mating is also important for placental and fetal growth and this is dependent on the level of feeding (Faichney \& White, 1987). Both quantity and quality of protein influence fetal growth in ewes as feeding of lupin grains, a source of extra protein, in late pregnancy has resulted in better lamb birth weight (Kleemann et al. 1988). Ewes bearing triplets, maintained only on high quality pastures, may even suffer from a deficiency in the supply of certain amino acids (Barry \& Manley, 1985), particularly cystine and histidine (Robinson et al. 1985).

\section{POSTPARTUM ANOESTROUS INTERVAL}

Reduction of the postparturient anoestrous period has received greatest attention in lactating animals. Protein and/or energy deficiency are common predisposing factors for prolonging the postparturient interval to first oestrus. Regaining threshold body weight is necessary for animals to come into regular oestrous cycles (Doney et al. 1982). The cows showing poor body condition exhibited extended postpartum oestrus intervals compared with those which were in good condition (Wright et al. 1987; Richards et al. 1989; Houghton et al. 1990). In developing countries, cattle and buffaloes kept mainly on grazing exhibited longer anoestrous periods extending from January to August due to inadequate availability of nutrients. During the late monsoon months (August \& September), grasslands show improvement with a flush of nutrients, leading to the so-called 'onset of breeding' season. Kaur \& Arora (1982) observed that the seasonal anoestrous period could be reduced to a great extent by improving the nutritional status of the animals. In Australia, the interval from calving to first oestrus was reduced from 75 to $40 \mathrm{~d}$ in grazing cows by giving a protein supplement along with phosphorus (Little, 1975). Sasser et al. (1988) reported an $11 \mathrm{~d}$ increase in postpartum oestrus interval in cows maintained on a low protein diet. On the other hand, intake of dietary protein above the feeding standards for maximizing milk yield have resulted in prolongation of the time from the day of calving to conception (Folman et al. 1981). It is expected that a large supply of undegradable dietary protein, that enhances milk yield and in turn stimulates the mobilization of body fat in early lactation, may accentuate the energy deficit and delay rebreeding (Ferguson \& Chalupa, 1989). Higher amounts of RDP may also extend the postpartum anoestrous period by delaying uterine involution (Carroll et al. 1988). Ducker et al. (1985) emphasized that maximum or peak milk yield at the time of insemination is detrimental to conception. Goodall \& McMurray (1984) predicted financial advantages or disadvantages of reducing the rebreeding interval by considering different feeding strategies, calving dates and reproductive performance values. Nutritional status affects the timing and magnitude of various hormones secreted during late pregnancy and early lactation and thus affects the postpartum anoestrous period. The mechanism is likely to be an alteration in the frequency of episodic release of LH necessary for fostering ovarian follicular development and ovulation. Alternatively, protein or energy deficiency in early lactation may render ovarian follicles less responsive to the gonadotrophin stimulus (McCann \& Hansel, 1986). The interval to first ovulation in the postpartum period therefore depends upon the process of recovery in the normal functions of the brain pituitary-ovarian axis and the genital tract. 


\section{POSSIBLE MECHANISMS OF EFFECTS OF PROTEIN NUTRITION ON REPRODUCTION}

Low as well as high levels of protein intake seem to be associated with reproductive disturbances in animals. Few mechanisms based on the amount of dietary protein intake, its digestion and metabolism can be postulated.

\section{PUBERTY}

Attainment of a particular body weight has been accepted as a pre-requisite for the onset of puberty. Acquisition of a minimum level of body fat is also considered to trigger pubertal endocrine changes (Randel, 1990), though there are reports that heifers reared on different planes of nutrition do not attain puberty at a consistent level of body fat (Brooks et al. 1985). Simpson et al. (1991) reported that prepubertal heifers which deposited more fat reached puberty at a later age. Hence, it is apparent that minimum body fat alone is not sufficient to trigger puberty. The important event leading to onset of puberty has been identified as the pre-pubertal increase in luteinizing hormone $(\mathrm{LH})$ pulse frequency which results from a decrease in responsiveness of the hypothalamic-pituitary axis to oestrogen negative feedback (Kinder et al. 1987). Undernutrition might delay puberty by inhibiting the pulsatile release of gonadotrophin releasing hormone $(\mathrm{GnRH})$ from the hypothalamus and thus might influence the pulsatile LH secretion (Moss et al. 1985; Foster \& Olster, 1985; Day et al. 1986), which is required to stimulate the development of ovarian follicles to the preovulatory stage. On GnRH injection in such underfed heifers, LH pulses were observed to be similar to those of normal animals (Kurz et al. 1990; Kile et al. 1991).

In addition, hypothalamic luteinizing hormone releasing hormone (LHRH) level was the same both in underfed and ad lib. fed lambs which suggested that the effect of feed restriction was on central mechanisms controlling LHRH release rather than on LHRH synthesis. It is further evident that $N$-methyl-D-aspartate activates the release of accumulated GnRH from the hypothalamus which is inhibited as a result of undernutrition (Ebling et al. 1990; I'Anson et al. 1990), suggesting that the central nervous system was responsible for the release of GnRH (Dunn \& Moss, 1992). Since dietary protein:energy ratios influence intermediary metabolism leading to changes in the circulatory concentrations of insulin, certain amino acids and non-esterified fatty acids (Brockman \& Laarveld, 1986; Howard et al. 1987; Patil, 1993), it is proposed that these metabolites may act as nutritional signals influencing LH secretion. Schillo (1992) reported that insulin and tyrosine enhance and non-esterified fatty acid inhibit the pulsatile secretion of LH in young sheep and that neurones controlling the pulsatile release of LHRH are responsive to the availability of these substances.

Insulin has been shown to bind with insulin specific receptors in the arcuate nucleus and median eminence areas of the brain to control GnRH secretion in mammals (van Houten et al. 1980; Duffy \& Pardridge, 1987; Wallum et al. 1987). Tyrosine administration has been shown to enhance the onset of puberty along with increased litter size in rats in some cases (Hammerl \& Muller, 1988), and in adult cows ovarian activity has been induced by tyrosine administration (Hammerl, 1986). The theory behind this action of tyrosine is increased synthesis of a catecholamine neurotransmitter in the central nervous system of rats and monkeys (Kalra \& Kalra, 1983; Terasawa et al. 1988; During et al. 1989). To elaborate further, Hall et al. (1990) studied the effect of tyrosine infusion for 22 days in ovariectomized feed restricted lambs and reported higher concentration of tyrosine in blood and hypothalamic tissue along with higher frequencies of LH pulses. It is therefore evident that any disruption in LH pulse frequency due to reduced supply of amino acids 
or energy may delay the onset of puberty in animals, though further research is still required to identify other metabolites which may mediate the effects of nutrition on LHRH release.

\section{LOW PROTEIN FEEDING EFFECTS ON FERTILITY}

Protein deficient cows develop hypoalbuminaemia which has been shown to correlate inversely with number of services per conception (Payne et al. 1970). Low protein diets reduce the efficiency of metabolizable energy utilization (MacRae et al. 1985) accompanied by reduced glucose entry rate and plasma glucose concentration (Linzell \& Peaker, 1971). Teleni et al. (1989) observed an increase in glucose entry rate in sheep when additional protein was presented to the small intestine by abomasal infusion of casein. Decreased plasma glucose concentration in protein restricted animals results in decreases in plasma insulin levels both of which can inhibit the pulsatile release of LH (Foster et al. 1989). Deficiency of certain amino acids may lead directly to alterations in the levels of certain hormones and their releasing factors. Intravenous infusion of amino acids or abomasal infusion of casein or increased intake of dietary protein have all been shown to elevate blood insulin, glucagon and glucose levels (Chew et al. 1984; Ladenheim et al. 1984; Blauwiekel et al. 1986; Cohick et al. 1986; Rutter \& Manns, 1987) and insulin in turn has been found to increase follicle stimulating hormone and progesterone in cultured pituitary and luteal cells (Adashi et al. 1981; Ladenheim et al. 1984). Moreover, immunoreactive insulin and insulin specific receptors have been identified in the arcuate nucleus and the median eminence areas of the brain (Havrankova et al. 1978; van Houten et al. 1980) which play an important role in the control of GnRH secretion in mammals. The normal frequency of LH pulses can be restored by either glucose infusion to severely diet restricted ewes (Foster et al. 1989) or by injections of GnRH (Vandalem, 1986). It is therefore evident that the decrease in the number of LH pulses is due to inhibition of the GnRH pulse generating stimulus rather than insufficiency of its synthesis and storage in the pituitary gland. However, full information on the mechanisms linking metabolic status to LHRH secretion is still lacking. A recently discovered peptide, neuropeptide Y (NPY), has been shown to provide a link between the control of feed intake and the secretion of GnRH. NPY infused cerebroventricularly suppresses the release of LH in ovariectomized rats, rabbits and monkeys (Kalra \& Crowley, 1984; Khorram et al. 1987, McDonald et al. 1989; Kaynard et al. 1990). In this connection, m-RNA of NPY is believed to be elevated in feed restricted rats, and in consequence the concentration of NPY is greater in specific hypothalamic regions such as the paraventricular and arcuate nuclei (Sahu et al. 1988). It seems that this higher concentration of NPY is inhibitory to the release of LH in ovariectomized non-oestrogen-treated animals (Sabatino et al. 1989). In a study conducted in ovariectomized sheep, NPY injections into the lateral ventricle had inhibitory effects on LH release (Malven et al. 1990; McShane et al. 1992). The pathway of the effects of low protein intake on LH secretion is depicted in Fig. 1.

\section{HIGH PROTEIN FEEDING EFFECTS ON FERTILITY}

Feeding more than the recommended amounts of protein or inclusion of excess degradable protein in the diet adversely affect animal reproduction. On such diets it is likely that relatively more ammonia is released in the rumen through the process of deamination by bacterial enzymes (Visek, 1984). The excess ammonia or urea produced in the rumen can diffuse from the alimentary tract to the peripheral circulation and appear in the uterine secretions (Jordan et al. 1983), thereby disturbing endocrine functions (Ferguson et al. 


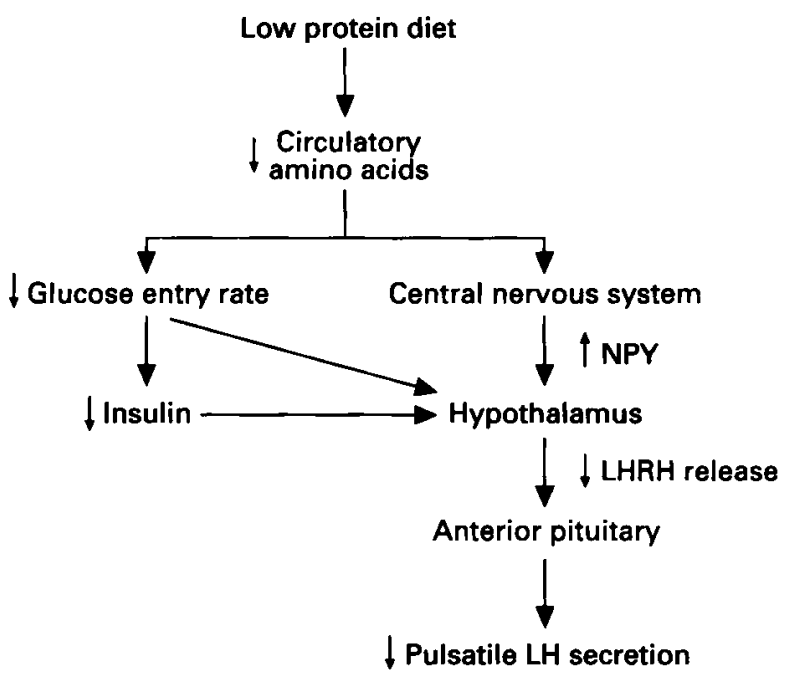

Fig. 1. Likely mechanisms for the effect of low dietary protein on pulsatile luteinizing hormone secretion.

LH, luteinizing hormone; LHRH, luteinizing hormone releasing hormone; NPY, neuropeptide Y.

1986) and the corpus luteum (Garwacki et al. 1979), and may also reduce motility and survival of sperms as a result of a changed uterine environment. The toxic effects of ammonia, urea or other unidentified nitrogenous compounds influence the survival of ova, sperms and early developing embryos (Umezaki \& Fordney-Settlage, 1975; Jordan et al. 1983; Sahlu et al. 1992). Excess protein, irrespective of protein source or degradability, decreases uterine $\mathrm{pH}$ on day 7 of the estrous cycle (Elrod \& Butler, 1993) by decreasing the uterine $\mathrm{Mg}, \mathrm{K}$ and $\mathrm{PO}_{4}$ concentrations during the luteal phase (Jordan et al. 1983) which can in turn inhibit the endometrial carbonic anhydrase activity (Rowlett et al. 1991). The decrease in $\mathrm{pH}$ in the uterus adversely affects the activity and survivability of sperms in the reproductive tract (White, 1974). Ferguson et al. (1988) suggested that dietary protein intakes producing serum urea- $\mathrm{N}$ greater than $200 \mathrm{mg} / \mathrm{l}$ were indicative of excess protein intake, particularly RDP.

High protein intake may also influence the reproductive system as a result of activation of different mechanisms in the liver for hepatic detoxification and the increase of energy demand for deamination of excess amino acids (Visek, 1984). Excess ammonia may also disturb intermediary metabolism and thus increase blood concentrations of urea, glucose, non-esterified fatty acids and insulin. Smith (1986) reported that some nitrogenous end products might alter the functioning of the hypophyseal-pituitary-ovarian axis by decreasing LH pulse frequency and amplitude. Fig. 2 illustrates the mechanism of action of excess dietary protein on LH secretion.

\section{CONCLUSIONS AND PERSPECTIVES}

There is considerable current interest in the influence of protein nutrition on reproduction of farm animals particularly in developing countries where dietary protein deficiency is common. In the developed world, excess protein is often fed to obtain more milk from high yielding animals. Both aspects of protein nutrition have implications for the reproduction process in primiparous as well as pluriparous animals. It is essential that the animals should be given adequate protein during the postweaning period to get optimum growth and early puberty. It is also well recognized that an increase in prepubertal LH pulse frequency is an 


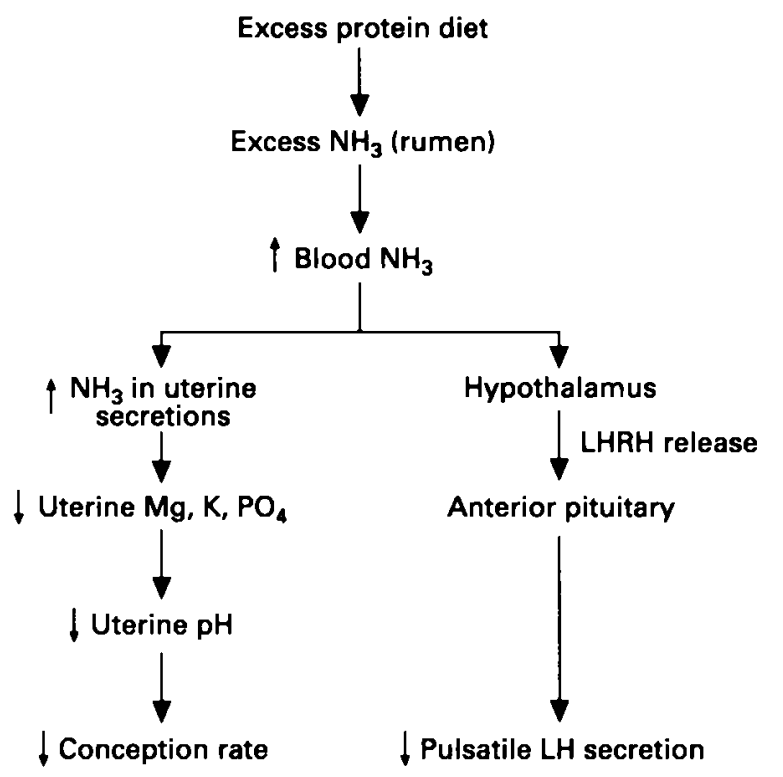

Fig. 2. Likely mechanisms for the effect of excess dietary protein on pulsatile luteinizing hormone secretion. LH, luteinizing hormone; LHRH, luteinizing hormone releasing hormone.

important event for the onset of puberty. Attention is now being paid to the cellular biochemical changes being mediated through certain amino acids which influence pulsatile LH secretion. Alterations in body metabolism as a result of deficiency of certain amino acids may influence the neuronal mechanisms linking nutritional status with the pulsatile release of LHRH. Further studies are required to identify the neurones controlling LHRH release from the hypothalamus with the generation of neuroendocrine signals.

In embryo biotechnology work, the influence of nutrition on donor and recipient animals needs to be investigated to promote ova recovery rate, embryo survival and embryo development, as this technique is now being used on a wider scale to generate superior progeny for increased milk production.

Studies are required to work out in detail the mode of action of feeding high protein diets on various events of the reproductive cycle. The results of such investigations may help to overcome failures in reproductive function without depressing milk yield. There is a distinct possibility of reducing the total protein by prescribing less RDP in the diet, so that no harm is done to the reproductive tract. Long term studies are also suggested to investigate the carry-over effects of different nutritional regimes, particularly dietary protein level.

\section{REFERENCES}

Abdul-Wahid, F. T., Tritschler, J. P. \& Duby, R. T. (1986). Effect of dietary crude protein on fertility and urea level in reproductive fluids of sheep. Journal of Animal Science 63 (Suppl. 1), 211-212 (Abstr).

Abecia, J. A., Forcada, F., Zarazaga, L. \& Lozano, J. M. (1993). Effect of plane of protein after weaning on resumption of reproductive activity in Rasa Aragonesa ewes lambing in late spring. Theriogenology 39, 463-473.

Adashi, E. Y., Hsueh, A. J. W. \& Yen, S. S. C. (1981). Insulin enhancement of luteinizing hormone and folliclestimulating hormone release by cultured pituitary cells. Endocrinology 108, 1441-1449.

Agricultural Research Council (1980). Nutrient Requirements of Ruminant Livestock: Technical Review. 2nd edn. Farnham Royal: Commonwealth Agricultural Bureaux.

Alkass, J. E., Bryant, M. J. \& Walton, J. S. (1982). Some effects of level of feeding and body condition upon sperm production and gonadotropin concentrations in the ram. Animal Production 34, $265-277$. 
Arije, G. F. \& Wiltbank, J. N. (1971). Age and weight at puberty in Hereford heifers. Journal of Animal Science 33, 401-406.

Ashworth, C. J. \& Bazer, F. W. (1989). Changes in ovine conceptus and endometrial function following asynchronous embryo transfer or administration of progesterone. Biology of Reproduction 40, 425-433.

Baird, D. T. \& McNeilly, A. S. (1981). Gonadotrophic control of follicular development and function during the oestrous cycle of the ewe. Journal of Reproduction and Fertility Suppl. 30, 119-133.

Barry, T. N. \& Manley, T. R. (1985). Glucose and protein metabolism in late pregnancy in triplet-bearing ewes given fresh forages ad lib. 1. Voluntary intake and birth weight. British Journal of Nutrition 54, 521-533.

Baruah, K. K. Jr., Baruah, R. N., Baruah, K. K. \& Baruah, B. (1986). The effect of diet on reproduction in Jersey heifers. Proceedings of 6 th National Congress on Animal Reproduction, P. G. Guwahati, India.

Bazer, F. W. (1989). Establishment of pregnancy in sheep and pigs. Reproduction, Fertility and Development 1, 237-242.

Berardinelli, J. G., Dailey, R. A., Butcher, R. L. \& Inskeep, E. K. (1979). Source of progesterone prior to puberty in beef heifers. Journal of Animal Science 49, 1276-1280.

Blauwiekel, R., Kincaid, R. L. \& Reeves, J. J. (1986). Effect of high crude protein on pituitary and ovarian function in Holstein cows. Journal of Dairy Science 69, 439-446.

Brockman, R. P. \& Laarveld, B. (1986). Hormonal regulation of metabolism in ruminants: a review. Livestock Production Science 14, 313-334.

Brooks, A. L., Morrow, R. E. \& Youngquist, R. S. (1985). Body composition of beef heifers at puberty. Theriogenology 24, 235-250.

Carroll, D. J., Barton, B. A., Anderson, G. W. \& Smith, R. D. (1988). Influence of protein intake and feeding strategy on reproductive performance of dairy cows. Journal of Dairy Science 71, 3470-3481.

Chew, B. P., Eisenman, J. R. \& Tanaka, T. S. (1984). Arginine infusion stimulates prolactin, growth hormone, insulin, and subsequent lactation in pregnant dairy cows. Journal of Dairy Science 67, 2507-2518.

Cohick, W. S., Vicini, J. L., Staples, C. R., Clark, J. H., McCutcheon, S. N. \& Bauman, D. E. (1986). Effects of intake and postruminal casein infusion on performance and concentration of hormones in plasma of lactating cows. Journal of Dairy Science 69, 3022-3031.

Corps, A. N., Littlewood, C. J. \& Brown, K. D. (1989). IGF binding proteins from pig pre-implantation blastocysts. In Biotechnology in Growth Regulation, p. 252 [R. B. Heap, C. G. Prosser and G. E. Lamming, editors]. London: Butterworths.

Davis, I. F., Brien, F. D., Findlay, J. K. \& Cumming, I. A. (1981). Interactions between dietary protein, ovulation rate and follicle stimulating hormone level in the ewe. Animal Reproduction Science 4, $19-28$.

Davis, R. F. (1978). Response of dairy cattle to ration protein of different solubilities. Proceedings of the Maryland Nutrition Conference for Feed Manufacturers pp. 116-120.

Day, M. L., Imakawa, K., Zalesky, D. D., Kittok, R. J. \& Kinder, J. E. (1986). Effects of restriction of dietary energy intake during the prepubertal period on secretion of luteinizing hormone and responsiveness of the pituitary to luteinizing hormone-releasing hormone on heifers. Journal of Animal Science 62, 1641-1648.

Doney, J. M., Gunn, R. G. \& Horák, F. (1982). Reproduction. In Sheep and Goat Production (World Animal Science C.1) pp. 57-80 [I. E. Coop, editor]. Amsterdam: Elsevier Scientific Publishing Company.

Ducker, M. J., Haggett, R. A., Fisher, W. J., Morant, S. V. \& Bloomfield, G. A.(1985). Nutrition and reproductive performance of dairy cattle. 1 . The effect of level of feeding in late pregnancy and around the time of insemination on the reproductive performance of first lactation dairy heifers. Animal Production 41, 1-12.

Duffy, K. R. \& Pardridge, W. M. (1987). Blood-brain barrier transcytosis of insulin in developing rabbits. Brain Research 420, 32-38.

Dufour, J. J. (1975). Influence of postweaning growth rate on puberty and ovarian activity in heifers. Canadian Journal of Animal Science 55, 93-100.

Dunn, T. G. (1980). Relationship of nutrition to successful embryo transplantation. Theriogenology 13, 27-40.

Dunn, T. G. \& Moss, G. E. (1992). Effects of nutrient deficiencies and excesses on reproductive efficiency of livestock. Journal of Animal Science 70, 1580-1593.

During, M. J., Acworth, I. N. \& Wurtman, R. J. (1989). Dopamine release in rat striatum: physiological coupling to tyrosine supply. Journal of Neurochemistry 52, 1449-1453.

Dýrmundsson, O. R. (1987). Advancement of puberty in male and female sheep. In New Techniques in Sheep Production, pp. 65-76 [I. F. M. Marai and J. B. Owen, editors]. London: Butterworths.

Ebling, F. J. P., Wood, R. I., Karsch, F. J., Vannerson, L. A., Suttie, J. M., Bucholtz, D. C., Schall, R. E. \& Foster, D. L. (1990). Metabolic interfaces between growth and reproduction. III. Central mechanisms controlling pulsatile luteinizing hormone secretion in the nutritionally growth-limited female lamb. Endocrinology 126, 2719-2727.

Elrod, C. C. \& Butler, W. R. (1993). Reduction of fertility and alteration of uterine pH in heifers fed excess ruminally degradable protein. Journal of Animal Science 71, 694701.

Faichney, G. J. \& White, G. A. (1987). Effects of maternal nutritional status on fetal and placental growth and on fetal urea synthesis in sheep. Australian Journal of Biological Sciences 40, 365-377.

Ferguson, J. D., Blanchard, T. L., Galligan, D. T., Hoshall, D. C. \& Chalupa, W. (1988). Infertility in dairy cattle fed a high percentage of protein degradable in the rumen. Journal of the American Veterinary Medical Association 192, 659-661. 
Ferguson, J. D., Blanchard, T. L., Shotzberger, S. \& Chalupa, W. (1986). Effect of rumen degradable protein on fertility. Journal of Dairy Science 69 (Suppl. 1), 121 (Abstr.).

Ferguson, J. D. \& Chalupa, W. (1989). Impact of protein nutrition on reproduction in dairy cows. Journal of Dairy Science 72, 746-766.

Fletcher, I. C., Putu Sede, I. \& Lubis, A. (1987). Nutritional constraints on reproduction in swamp buffalo cows. Proceedings of International Symposium on Milk Buffalo Reproduction, Islamabad, Pakistan, p. 27.

Folman, Y., Neumark, H., Kaim, M. \& Kaufmann, W. (1981). Performance, rumen and blood metabolites in high-yielding cows fed varying protein percents and protected soybean. Journal of Dairy Science 64, 759-768.

Folman, Y., Rosenberg, M., Ascarelli, I, Kalm, M. \& Herz, Z. (1983). The effect of dietary and climatic factors on fertility and on plasma progesterone and oestradiol-17 $\beta$ levels in dairy cows. Journal of Steroid Biochemistry 19, 863-868.

Foote, R. H. (1978). Factors influencing the quantity and quality of semen harvested from bulls, rams, boars and stallions. Journal of Animal Science 47, (Suppl. 2) 1-11.

Foster, D. L., Ebling, F. J. P., Micka, A. F., Vannerson, L. A., Bucholtz, D. C., Wood, R. I., Suttie, J. M. \& Fenner, D. E. (1989). Metabolic interfaces between growth and reproduction. I. Nutritional modulation of gonadotropin, prolactin, and growth hormone secretion in the growth-limited female lamb. Endocrinology 125, 342-350.

Foster, D. L., Ebling, F. J. P., Vannerson, L. A., Bucholtz, D. C., Wood, R. I., Micka, A. F., Suttie, J. M. \& Veenvliet, B. A. (1988). Modulation of gonadotrophin secretion during development by nutrition and growth. Proceedings of Ilth International Congress on Animal Reproduction and Artificial Insemination, University College Dublin, 5, 101-108.

Foster, D. L. \& Olster, D. H. (1985). Effect of restricted nutrition on puberty in the lamb: patterns of tonic luteinizing hormone (LH) secretion and competency of the LH surge system. Endocrinology 116, 375-381.

Garwacki, S., Wiechetek, M. \& Barej, W. (1979). Comparison of metabolic effect of ammonia and adrenaline infusions in sheep. Quarterly Journal of Experimental Physiology 64, 23-29.

Goodall, E. A. \& McMurray, C. H. (1984). An integration of mathematical models for feeding and lactation with reproductive performance of the dairy cow. Animal Production 38, 341-349.

Hall, J. B., Schillo, K. K., Hileman, S. M. \& Boling, J. A. (1990). Does tyrosine act as a nutritional signal mediating the effects of increased feed intake on luteinizing hormone patterns in growth-restricted lambs? Biology of Reproduction 46, 573-579.

Hammerl, J. (1986). [The effect of amino acid L-tyrosine on a catecholamine precursor, in the reproduction of cows.] In Proceedings of the 14th World Congress on Diseases of Cattle, Dublin, p. 911.

Hammerl, J. \& Muller, P. (1988). [The effect of L-tyrosine on reproduction in rats.] Tierärztliche Umschau 43, $450-452$.

Havrankova, J., Schmechell, D., Roth, J. \& Brownstein, M. (1978). Identification of insulin in rat brain. Proceedings of National Academy of Sciences of the USA 75, 5737-5741.

Henniawati \& Fletcher, I. C. (1986). Reproduction in Indonesian sheep and goats at two levels of nutrition. Animal Reproduction Science 12, 77-84.

Houghton, P. L., Lemenager, R. P., Horstman, L. A., Hendrix, K. S. \& Moss, G. E. (1990). Effects of body composition, pre- and postpartum energy level and early weaning on reproductive performance of beef cows and preweaning calf gain. Journal of Animal Science 68, 1438-1446.

Howard, H. J., Aalseth, E. P., Adams, G. D., Bush, L. J., McNew, R. W. \& Dawson, L. J. (1987). Influence of dietary protein on reproductive performance of dairy cows. Journal of Dairy Science 70, 1563-1571.

I'Anson, H., Wood, R. I., Bucholtz, D. C. \& Padmanabhan, V. (1990). Hypothalamic vs pituitary stimulation of LH release in the prepubertal female lamb. Biology of Reproduction 42 (Suppl. 1), 47 (Abstr.).

Jordan, E. R., Chapman, T. E., Holtan, D. W. \& Swanson, L. V. (1983). Relationship of dietary crude protein to composition of uterine secretions and blood in high-producing postpartum dairy cows. Journal of Dairy Science 66, 1854-1862.

Juneja, S. C. \& Arora, S. P. (1986). Influence of level of nutrition and body weight on fertility in crossbred cows. Journal of Nuclear Agriculture \& Biology 15, 67-70.

Juneja, S. C. \& Arora, S. P. (1989). Occurrence of oestrus depressed by undernutrition in crossbred cows. Indian Journal of Animal Nutrition 6, 194-199.

Juneja, S. C. \& Arora, S. P. (1990). Oestrous behaviour and annual pattern of peripheral progesterone in crossbred cows at two levels of nutrition. Indian Journal of Animal Reproduction 11, 31-34.

Kaim, M., Folman, Y. \& Neumark, H. (1983). The effect of protein intake and lactation number on post-partum body weight loss and reproductive performance of dairy cows. Animal Production 37, 229-235.

Kalra, S. P. \& Crowley, W. R. (1984). Norepinephrine-like effects of neuropeptide Y on LH release in the rat. Life Science 35, 1173-1176.

Kalra, S. P. \& Kalra, P. S. (1983). Neural regulation of luteinizing hormone secretion in the rat. Endocrinology Reviews 4, 311-351.

Karsch, F. J. (1984). Endocrine and environmental control of oestrous cyclicity in sheep. In Reproduction in Sheep, pp. 10-15 [D. R. Lindsay and D. T. Pearce, editors]. Cambridge: Cambridge University Press.

Kaur, H. (1981). Studies on Progesterone Levels in Blood Plasma of Normal Cycling Buffaloes as Influenced by Different Levels of Nutrition. Ph.D. Thesis, Kurukshetra University, Kurukshetra. 
Kaur, H. (1993). Nutritional regulation of animal reproduction. Proceedings of the Sixth Animal Nutrition Research Workers' Conference, Bhubaneshwar, India, pp. 143-149.

Kaur, H. \& Arora, S. P. (1982). Influence of level of nutrition and season on the oestrus cycle rhythm and on fertility in buffaloes. Tropical Agriculture 59, 274-278.

Kaur, H. \& Arora, S. P. (1989). Growth and puberty as influenced by plane of nutrition in Murrah buffaloes. Buffalo Journal 5, 57-64.

Kaynard, A. H., Pau, K.-Y. F., Hess, D. L. \& Spies, H. G. (1990). Third-ventricular infusion of neuropeptide Y suppresses luteinizing hormone secretion in ovariectomized rhesus macaques. Endocrinology 127, $2437-2444$.

Ketut Sutama, I. \& Edey, T. N. (1985). Reproductive development during winter and spring of Merino ram lambs grown at three different rates. Australian Journal of Agricultural Research 36, 461-467.

Khasan, A. M., Tashev, T. \& Todorov, N. A. (1989). [The effect of level of dietary protein on the production and conception of cows.] Zhivotnovudni Nauki 26, 3-10 (Nutrition Abstracts and Reviews B 60, 452.)

Khorram, O., Pau, K.-Y. F. \& Spies, H. G. (1987). Bimodal effects of neuropeptide Y on hypothalamic release of gonadotropin-releasing hormone in conscious rabbits. Neuroendocrinology 45, 290-297.

Kile, J. P., Alexander, B. M., Moss, G. E., Hallford, D. M. \& Nett, T. M. (1991). Gonadotropin-releasing hormone overrides the negative effect of reduced dietary energy on gonadotropin synthesis and secretion in ewes. Endocrinology 128, 843-849.

Kinder, J. E., Day, M. L. \& Kittock, R. J. (1987). Endocrine regulation of puberty in cows and ewes. Journal of Reproduction and Fertility Suppl. 34, 167-186.

Kleemann, D. O., Walker, S. K., Walkley, J. R. W., Smith, D. H., Grimson, R. J., Stafford, J. E. \& Seamark, R. F. (1988). The effect of nutrition during mid and late pregnancy on lamb birthweight and survival in F + Booroola $\times$ S. A. Merino ewes. Proceedings of the Australian Society of Animal Production 17, 428.

Kurz, S. G., Dyer, R. M., Hu, Y., Wright, M. D. \& Day, M. L. (1990). Regulation of luteinizing hormone secretion in prepubertal heifers fed an energy-deficient diet. Biology of Reproduction 43, $450-456$.

Ladenheim, R. G., Tesone, M. \& Charreau, E. H. (1984). Insulin action and characterization of insulin receptors in rat luteal cells. Endocrinology 115, 752-756.

Lamond, D. R. (1970). The influence of undernutrition on reproduction in the cow. Animal Breeding Abstracts 38, 359-372.

Leng, R. A. (1990). Nutrition of ruminants at pasture in the tropics: implications for selection criteria. Proceedings of the $4 \mathrm{th}$ World Congress on Genetics Applied to Livestock Production. Edinburgh, U.K. pp. 298-309.

Leng, R. A. \& Nolan, J. V. (1984). Nitrogen metabolism in the rumen. Journal of Dairy Science 67, $1072-1089$.

Lindsay, J. A, Ndama, P. H., Tune, D. R., Toleman, M. A. \& Entwhistle, K. W. (1982). Protected proteins as supplements for bulls fed tropical forage diets. Proceedings of the Australian Society of Animal Production 14, 594.

Linzell, J. L. \& Peaker, M. (1971). Mechanism of milk secretion. Physiological Reviews 51, 564-597.

Little, D. A. (1975). Effects of dry season supplements of protein and phosphorus to pregnant cows on the incidence of first post-partum oestrus. Australian Journal of Experimental Agriculture and Animal Husbandry 15, 25-31.

Loudon, A. (1987). Nutritional effects on puberty and lactational infertility in mammals: some interspecies considerations. Proceedings of the Nutrition Society 46, 203-216.

Louw, B. P., Thomas, C. R. \& Lishman, A. W. (1988). The influence of loss and gain of body mass on ovarian activity in beef cows. South African Journal of Animal Science 18, 1-7.

McCann, J. P. \& Hansel, W. (1986). Relationships between insulin and glucose metabolism and pituitary-ovarian functions in fasted heifers. Biology of Reproduction 34, 630-641.

McDonald, J. K., Lumpkin, M. D. \& DePaolo, L. V. (1989). Neuropeptide-Y suppresses pulsatile secretion of luteinizing hormone in ovariectomized rats: possible site of action. Endocrinology 125, 186-191.

McKelvey, W. A. C. \& Robinson, J. J. (1986). Embryo survival and growth in the ewe - recent studies on the effects of nutrition and on novel techniques for the recovery and transfer of embryos. Annual Report of Studies in Animal Nutrition and Allied Sciences, Rowett Research Institute 41, 9-25.

McKelvey, W. A. C. \& Robinson, J. J. (1988). The use of reciprocal embryo transfer to separate the effects of preand post-mating nutrition on embryo survival and growth of ovine conceptus. In Proceedings of 11th International Congress on Animal Reproduction and Artificial Insemination, University College, Dublin, 2, Paper no. 176.

MacRae, J. C., Smith, J. S., Dewey, P. J. S., Brewer, A. C., Brown, D. S. \& Walker, A. (1985). The efficiency of utilization of metabolizable energy and apparent absorption of amino acids in sheep given spring- and autumnharvested grass. British Journal of Nutrition 54, 197-209.

McShane, T. M., May, T., Miner, J. L. \& Keisler, D. H. (1992). Central actions of neuropeptide-Y may provide a neuromodulatory link between nutrition and reproduction. Biology of Reproduction 46, 1151-1157.

Malik, M. Y. (1987). Reproductive performance of buffaloes as affected by nutritional imbalances. Proceedings of International Symposium on Milk Buffalo Reproduction, Islamabad, Pakistan, p. 35.

Malven, P. V., Haglof, S. A. \& De Groot, H. (1990). Intraventricular administration of neuropeptide Y (NPY) inhibits LH release in ovariectomized sheep. Neuroscience 16, 394 (Abstr.).

Meaker, H. J. (1976). The influence of different planes of nutrition during winter on the conception rate of heifers. South African Journal of Animal Science 6, 21-23. 
Moss, G. E., Parfet, J. R., Marvin, C. A., Allrich, R. D. \& Diekman, M. A. (1985). Pituitary concentrations of gonadotropins and receptors for $\mathrm{GnRH}$ in suckled beef cows at various intervals after calving. Journal of Animal Science 60, 285-293.

Nolan, C. J., Neuendorff, D. A., Godfrey, R. W., Hams, P. G., Welsh, T. H., McArthur, N. H. \& Randel, R. D. (1990). Influence of dietary energy intake on prepubertal development of Brahman bulls. Journal of Animal Science 68, 1087-1096.

Nottle, M. B., Hynd, P. I., Seamark, R. F. \& Setchell, B. P. (1988). Increases in ovulation rate in lupin-fed ewes are initiated by increases in protein digested post-ruminally. Journal of Reproduction and Fertility 84, 563-566.

National Research Council (1978). Nutrient Requirements of Domestic Animals, No. 2, Nutrient Requirements of Dairy Cattle, 5th edn. Washington, DC: National Academy of Sciences, National Research Council.

National Research Council (1989). Nutrient Requirements of Cattle. Washington, DC: National Academy Press.

Oldham, C. M., Adams, N. R., Gherardi, P. B., Lindsay, D. R. \& Mackintosh, J. B. (1978). The influence of level of feed intake on sperm-producing capacity of testicular tissue in the ram. Australian Journal of Agricultural Research 29, 173-179.

Oldham, J. D. (1984). Protein-energy interrelationships in dairy cows. Journal of Dairy Science 67, $1090-1114$.

Oyedipe, E. O., Osori, D. I. K., Akerejola, O. \& Saror, D. (1982). Effect of level of nutrition on onset of puberty and conception rates of zebu heifers. Theriogenology 18, 525-539.

Pangborn, M. C. (1978). The Effect of Various Levels of Crude Protein on High Producing Dairy Cows in Early Lactation. M.S. thesis, Oregon State University.

Parker, G. V. \& Thwaites, C. J. (1972). The effects of undernutrition on libido and semen quality in adult Merino rams. Australian Journal of Agricultural Research 23, $109-115$.

Parr, R. A., Cumming, I. A. \& Clarke, I. J. (1982). Effects of maternal nutrition and plasma progesterone concentrations on survival and growth of the sheep embryo in early gestation. Journal of Agricultural Science 98, 39-46.

Parr, R. A., Davis, I. F., Fairclough, R. J. \& Miles, M. A. (1987). Overfeeding during early pregnancy reduces peripheral progesterone concentration and pregnancy rate in sheep. Journal of Reproduction and Fertility 80 , 317-320.

Parr, R. A., Williams, A. H., Campbell, I. P., Witcombe, G. F. \& Roberts, A. M. (1986). Low nutrition of ewes in early pregnancy and the residual effect on the offspring. Journal of Agricultural Science 106, 81-87.

Patil, N. V. (1993). Dietary Influence of Rumen Degradable Protein on Blood Metabolites and Some Hormones in Cycling and Pregnant Goats. Ph.D. Thesis, National Dairy Research Institute (Deemed University), Karnal, India.

Payne, J. M., Dew, S. M., Manston, R. \& Faulks, M. (1970). The use of a metabolic profile test in dairy herds. Veterinary Record 87, 150-158.

Pearse, B. H. G., McMeniman, N. P. \& Dowsett, K. F. (1991). Effect of lupin (Lupinus angustifolius) supplementation on ovarian and pituitary activity in ewes. Reproduction, Fertility and Development 33, $109-112$.

Perry, V. E. A., Chenoweth, P. J., Post, T. B. \& Munro, R. K. (1991). Patterns of development of gonads, sexdrive and hormonal responses in tropical beef bulls. Theriogenology 35, 473-486.

Radford, H. M., Donegan, S. \& Scaramuzzi, R. J. (1980). The effect of supplementation with lupin grain on ovulation rate and plasma gonadotrophin levels in adult Merino ewes. Proceedings of Australian Society of Animal Production 13, 457 (Abstr.).

Randel, R. D. (1990). Nutrition and postpartum rebreeding in cattle. Journal of Animal Science 68, 853-862.

Rekwot, P. I., Oyedipe, E. O., Akerejola, O. O. \& Kumi-Diaka, J. (1988). The effect of protein intake on body weight, scrotal circumference and semen production of Bunaji bulls and their Friesian crosses in Nigeria. Animal Reproduction Science 16, 1-9.

Rekwot, P. I., Oyedipe, E. O., Akerejola, O. O., Kumi-Diaka, J. \& Umoh, J. E. (1987). The effect of protein intake on the onset of puberty in Bunaji and Friesian $\times$ Bunaji crossbred bulls in Nigeria. Theriogenology 28, $427-434$.

Rhind, S. M., Leslie, I. D., Gunn, R. G. \& Doney, J. M. (1986). Effects of high levels of body condition and food intake on plasma follicle stimulating hormone, luteinizing hormone, prolactin and progesterone profiles around mating in Greyface ewes. Animal Production 43, 101-107.

Rhind, S. M., McKelvey, W. A. C., McMillen, S., Gunn, R. G. \& Elston, D. A. (1989). Effect of restricted food intake, before and/or after mating, on the reproductive performance of Greyface ewes. Animal Production 48 , 149-155.

Rhind, S. M. \& McNeilly, A. S. (1986). Follicle populations, ovulation rates and plasma profiles of LH, FSH and prolactin in Scottish Blackface ewes in high and low levels of body condition. Animal Reproduction Science 10, 105-115.

Richards, M. W., Wettemann, R. P. \& Schoenemann, H. M. (1989). Nutritional anestrus in beef cows: body weight change, body condition, luteinizing hormone in serum and ovarian activity. Journal of Animal Science 67, 1520-1526.

Ritar, A. J. \& Adams, N. R. (1988). Increased ovulation rate, but not FSH or LH concentrations, in ewes supplemented with lupin grain. Proceedings of the Australian Society of Animal Production 17, 310-313.

Robinson, J. J. (1983). Nutrition of pregnant ewe. In Sheep Production, pp. 111-113 [W. Haresign, editor]. London: Butterworths.

Robinson, J. J. (1986). Nutrition and embryo loss in farm animals. In Embryonic Mortality in Farm Animals, pp. 235-248 [J. M. Sreenan and M. G. Diskin, editors]. Dordrecht: Martinus Nijhoff Publishers. 
Robinson, J. J. (1990). Nutrition in the reproduction of farm animals. Nutrition Research Reviews 3, $253-276$.

Robinson, J. J. \& McDonald, D. I. (1989). Ewe nutrition and foetal growth and development. In Reproduction, Growth and Nutrition in Sheep, pp. 57-77 [Ó. R. Dýrmundsson and S. Thorgeirsson, editors]. Reykjavik: Agricultural Research Institute and Agricultural Society of Iceland.

Robinson, J. J. \& McDonald, I., Brown, D. S. \& Fraser, C. (1985). Studies on reproduction in prolific ewes. 8. The concentrations and rates of accretion of amino acids in the foetuses. Journal of Agricultural Science 105, 21-26.

Rowlett, R. S., Gargiulo, N. J., Santoli, F. A., Jackson, J. M. \& Corbett, A. H. (1991). Activation and inhibition of bovine carbonic anhydrase III by dianions. Journal of Biological Chemistry 266, 933-941.

Rutter, L. M. \& Manns, J. G. (1987). Hypoglycemia alters pulsatile luteinizing hormone secretion in the postpartum beef cow. Journal of Animal Science 64, 479-488.

Sabatino, F. D., Collins, P. \& McDonald, J. K. (1989). Neuropeptide-Y stimulation of luteinizing hormonereleasing hormone secretion from the median eminence in vitro by estrogen-dependent and extracellular $\mathrm{Ca}^{2+}$-independent mechanisms. Endocrinology 124, 2089-2098.

Sahlu, T., Fernandez, J. M., Lu, C. D. \& Potchoiba, M. J. (1992). Influence of dietary protein on performance of dairy goats during pregnancy. Journal of Dairy Science 75, 220-227.

Sahu, A., Kalra, P. S. \& Kalra, S. P. (1988). Food deprivation and ingestion induced reciprocal changes in neuropeptide Y concentrations in the paraventricular nucleus. Peptides 9, 83-86.

Sasser, R. G., Williams, R. J., Bull, R. C., Ruder, C. A. \& Falk, D. G. (1988). Postpartum reproductive performance in crude protein-restricted beef cows: return to estrus and conception. Journal of Animal Science 66, 3033-3039.

Schillo, K. K. (1992). Effects of dietary energy on control of luteinizing hormone secretion in cattle and sheep. Journal of Animal Science 70, 1271-1282.

Schillo, K. K., Hall, J. B. \& Hileman, S. M. (1992). Effects of nutrition and season on the onset of puberty in the beef heifer. Journal of Animal Science 70, 3994-4005.

Shokamoto, S., Imaizumi, E. \& Shijimaya, K. (1975). [The effect of different planes of nutrition during growth on the productivity of Holstein cows. III. Growth to first calving for two groups of cows calving at the same body weight.] Hokkaido National Agricultural Experiment Station Research Bulletin no. 110, 45-58 (Animal Breeding Abstracts 43, 676).

Simpson, R. B., Armstrong, J. D., Harvey, R. W., Miller, D. C., Heimer, E. P. \& Campbell, R. M. (1991). Effect of active immunization against growth hormone-releasing factor on growth and onset of puberty in beef heifers. Journal of Animal Science 69, $4914-4924$.

Smith, J. F. (1988). Influence of nutrition on ovulation rate in the ewe. Australian Journal of Biological Sciences 41, 27-36.

Smith, J. F., Payne, E., Peterson, A. J., McGowan, L. T., Cope, B. \& McLaughlin, R. (1990). Effects of phenobarbital, dietary protein intake, and ewe liveweight on ovulation rate and concentrations of plasma FSH and hepatic microsomal enzymes. Reproduction, Fertility and Development 2, 623-632.

Smith, M. F. (1986). Recent advances in corpus luteum physiology. Journal of Dairy Science 69, 911-926.

Smith, R. K. \& Day, M. L. (1990). Mechanisms of induction of puberty in beef heifers with melengestrol acetate. Ohio State Beef Research Report p. 137.

Stevenson, J. S. \& Call, E. P. (1988). Reproductive disorders in the periparturient dairy cow. Journal of Dairy Science 71, 2572-2583.

Stewart, R. \& Oldham, C. M. (1986). Feeding lupins to ewes for four days during the luteal phase can increase ovulation rate. Proceedings of Australian Society of Animal Production 16, 367-369.

Stone, B. A. (1987). Determinants of embryonic mortality in the pig. Pig News and Information 8, $279-284$.

Swanson, L. V. (1989). Discussion - interactions of nutrition and reproduction. Journal of Dairy Science 72 , $805-814$

Symonds, H. W. \& Prime, G. (1989). The influence of volume of food intake by gilts on blood flow in the portal vein and clearance of progesterone from plasma. Animal Production 48, 620-621.

Tegegne, A., Entwistle, K. W. \& Mukasawa-Mugerwa, E. (1992). Nutritional influences on growth and onset of puberty in Boran and Boran $\times$ Friesian bulls in Ethiopia. Theriogenology 37, 1005-1016.

Teleni, E., Rowe, J. B., Croker, K. P., Murray, P. J. \& King, W. R. (1989). Lupins and energy-yielding nutrients in ewes. 2. Responses in ovulation rate in ewes to increased availability of glucose, acetate and amino acids. Reproduction, Fertility and Development 1, 117-125.

Terasawa, E., Krook, C., Hei, D. L., Gearing, M., Schultz, N. J. \& Davis, G. A. (1988). Norepinephrine is a possible neurotransmitter stimulating pulsatile release of luteinizing hormone-releasing hormone in the rhesus monkey. Endocrinology 123, 1808-1816.

Thatcher, W. W., McMillan, K. L., Hansen, P. J. \& Drost, M. (1989). Concepts for regulation of corpus luteum function by the conceptus and ovarian follicles to improve fertility. Theriogenology 31, 149-164.

Thomas, D. L., Thomford, P. J., Crickman, J. G., Cobb, A. R. \& Dziuk, P. J. (1987). Effects of plane of nutrition and phenobarbital during the pre-mating period on reproduction in ewes fed differentially during the summer and mated in the fall. Journal of Animal Science 64, 1144-1152.

Topps, J. H. (1977). The relationship between reproduction and undernutrition in beef cattle. World Review of Animal Production 13(2), 43-49. 
Topps, J. H., Islam, M. N., Brodbent, P. J. \& Paterson, G. F. M. (1989). Effect of pre-calving nutrition on the performance of twin bearing beef cows and their calves. Animal Production 48, 617.

Treacher, R. J., Little, W., Collis, K. A. \& Stark, A. J. (1976). The infuence of dietary protein intake on milk production and blood composition of high-yielding dairy cows. Journal of Dairy Research 43, 357-369.

Umezaki, C. \& Fordney-Settlage, D. S. (1975). In vitro studies on cervical conception; use of urea as a spermicidal agent. Contraception 12, 465-493.

Vandalem, J. L. (1986). [Contribution to a study of the functions of the gonads and thyroid gland: an integrated approach.] Université de Liège, Belgium: Faculté de Médecine.

VanDemark, N. L., Fritz, G. R. \& Mauger, R. E. (1964). Effect of energy intake on reproductive performance of dairy bulls. II. Semen production and replenishment. Journal of Dairy Science 47, 898-904.

van Houten, M., Posner, B. I., Kopriwa, B. M. \& Brawer, J. R. (1980). Insulin binding sites localized to nerve terminals in rat median eminence and arcuate nucleus. Science 207, 1081-1083.

Vincent, l. C., Williams, H. LI. \& Hill, R. (1985). The influence of low-nutrient intake after mating on gestation and perinatal survival of lambs. British Veterinary Journal 141, 611-617.

Visek, W. J. (1984). Ammonia: its effects on biological systems, metabolic hormones, and reproduction. Journal of Dairy Science 67, 481-498.

Waddad, S. A. \& Gaili, E. S. E. (1985). Effect of nutrition on sexual development of Western Sudan Baggara bull calves. Acta Veterinaria, Beograd 35, 299-304.

Waghorn, G. C. \& Smith, J. F. (1990). The effect of protein and energy intake on physiological parameters and ovulation rate in ewes. Proceedings of Australian Society of Animal Production 18, 563.

Waghorn, G. C., Smith, J. F. \& Ulyatt, M. J. (1990). Effect of protein and energy intake on digestion and nitrogen metabolism in wethers and on ovulation in ewes. Animal Production 51, 291-300.

Wallum, B. J., Taborsky, G. J., Porte, D., Figlewicz, D. P., Jacobson, L., Beard, J. C., Ward, W. K. \& Dorsa, D. (1987). Cerebrospinal fuid insulin levels increase during intravenous insulin infusions in man. Journal of Clinical Endocrinology and Metabolism 64, 190-201.

White, L. G. (1974). Mammalian semen. In Reproduction in Farm Animals, 3rd Edn, p. 119. [E. S. E. Hafez, editor]. Philadelphia, PA: Lea \& Febiger.

Wohlt, J. E. \& Clark, J. H. (1978). Nutritional value of urea versus preformed protein for ruminants. 1. Lactation of dairy cows fed corn based diets containing supplemental nitrogen from urea and/or soybean meal. Journal of Dairy Science 61, 902-915.

Wright, I. A., Rhind, S. M., Russel, A. J. F., Whyte, T. K., McBean, A. J. \& McMillen, S. R. (1987). Effects of body condition, food intake and temporary calf separation on the duration of the post-partum anoestrous period and associated LH, FSH and prolactin concentrations in beef cows. Animal Production 45, $395-402$.

Wright, I. A., Russel, A. J. F. \& Hunter, E. A. (1986). The use of body condition scoring to ration beef cows in late pregnancy. Animal Production 43, 391-396.

Xu, Z. Z., McDonald, M. F. \& McCutcheon, S. N. (1989). The effects of nutritionally-induced liveweight differences on follicular development, ovulation rate, oestrous activity and plasma follicle-stimulating hormone levels in the ewe. Animal Reproduction Science 19, 67-78. 